Bull. Environ. Contam. Toxicol. (2003) 71:919-923

(c) 2003 Springer-Verlag New York Inc.

DOI: $10.1007 / \mathrm{s} 00128-003-0217-8$

\title{
Environmental Behavior of the Herbicide Acetochlor in Soil
}

C. $\mathrm{Ye}$

Research Center for Eco-Environmental Sciences, Chinese Academy of Science, Beijing 100085, People's Republic of China

Received: 31 August 2002/Accepted: 30 June 2003

Acetochlor [2-chloro-N-(ethoxymethyl)-N-(2-ethyl-6-methylphenyl) acetamide] is one of the most widely applied herbicides for controlling competing grasses and some broadleaf weeds in corn field (Capel, 1995 ), and has been classified as a B-2 carcinogen by the USEPA ( USEPA, 1994 ). About 10 million $\mathrm{kg}$ of acetochlor (active ingredient) has been applied every year since 1977 in China ( Wang, 1999). Acetochlor was one of the most widely used agricultural herbicides in China.

The environmental aspects of acetochlor use are of current concern because of its presence in surface and ground waters in most agricultural regions ( Karlkhoff, 1998; Clark, 1999). This is particularly the case with acetochlor, where a considerable portion of the applied herbicide may be lost from the target, mostly due to processes such as adsorption, degradation, runoff and leaching. The investigation of environmental behavior and fate of acetochlor in soils is of great significance for raising utilization efficiency and reducing groundwater contamination of this herbicide.

Through field and laboratory experiments, the processes of adsorption, biodegradation, hydrolysis, and dissipation dynamics of acetochlor in soils were studied. We also investigated influences of humic acid (HA) and anionic surfactant sodium dodecylbenzene sulfonate (SDBS) on the behavior of acetochlor in soils. The studied field was located at the corn field of Northwestern Beijing, where acetochlor has been applied for about 10 years.

\section{MATERIALS AND METHODS}

Soil samples were taken from top $10 \mathrm{~cm}$ layer at the agricultural field of Northwestern Beijing that did not receive previous application of the herbicide. The bulk soil was slightly air-dried, thoroughly mixed, and passed through $0.15 \mathrm{~mm}$ sieves. Analyzed soil properties include $\mathrm{pH}$, organic carbon (OC), cation exchange capacity (CEC) and particle-size distribution (Table 1).

Acetochlor in soil and water was analyzed by LC-6A High Performance Liquid Chromatography (HPLC) with Shimadzu Spectrophotometric Detector (SPD-3). The detection wavelength was $210 \mathrm{~nm}$. The mobile phase was methanol-water $(80 / 20, \mathrm{v} / \mathrm{v})$ with a flow rate of $1.0 \mathrm{ml} / \mathrm{min}$.

The procedures of extracting acetochlor from soil samples were: $20 \mathrm{~g}$ of soil sample and 40 $\mathrm{ml}$ acetone solution of $80 \%$ were placed into $500 \mathrm{ml}$ of centrifuge tube, and extracted on ultrasonic oscillator for $10 \mathrm{~min}$. The suspended solution in centrifuge tube was separated with $3000 \mathrm{rpm}$ of centrifuge. The above extraction procedure was repeated 3 times and three extracts were combined. The combined extract was concentrated on rotatory evaporator to remove most of the acetone. The concentrated residue was transferred into a $100 \mathrm{ml}$ separated 
Table 1. Physical and chemical properties of the soil

\begin{tabular}{llclcc}
\hline PH & $\begin{array}{c}\text { OC } \\
(\%)\end{array}$ & $\begin{array}{c}\text { CEC } \\
(\mathrm{mmol} / 100 \mathrm{~g})\end{array}$ & $\begin{array}{l}\text { silt } \\
(\%)\end{array}$ & $\begin{array}{c}\text { sandy } \\
(\%)\end{array}$ & $\begin{array}{c}\text { clay } \\
(\%)\end{array}$ \\
\hline 8.4 & 1.5 & 84.0 & 59 & 38 & 3 \\
\hline
\end{tabular}

funnel with $40 \mathrm{ml}$ water and $3 \mathrm{~g} \mathrm{NaCl}$, and extracted two times with $30 \mathrm{ml}$ petroleum ether. The two extracts were combined and concentrated near dry on rotatory evaporator, and then totally dried under a stream of $\mathrm{N}_{2}$ for $\mathrm{HPCL}$ analysis.

The water samples were extracted into petroleum ether and concentrated to about $3 \mathrm{ml}$ under reduced pressure. The concentrated extract was directly dried under a gentle stream of nitrogen gas and the residue was dissolved in $1 \mathrm{ml}$ of methanol, and then analyzes by HPLC.

Standard solution $\left(1.42 \mathrm{ml} 352 \mathrm{mg} . \mathrm{I}^{-1}\right)$ of acetochlor was taken into test tubes and were diluted to $25 \mathrm{ml}$ using $\mathrm{pH} 4, \mathrm{pH} 7$ and $\mathrm{pH} 10$ distilled waters containing $1 \% \mathrm{NaN}_{3}$ as a biocide respectively. All test tubes were screw caped, and placed into an incubator at $25 \pm 1{ }^{\circ} \mathrm{C} .20 \mu \mathrm{l}$ sample was taken from test tubes for acetochlor measurement at regular intervals.

Twenty g soil sample was placed into a $100 \mathrm{ml}$-Erlemeyer, in which acetochlor was added and mixed homogenously to obtain test sample that contained $10 \mathrm{mg} \cdot \mathrm{kg}^{-1}$ acetochlor. Samples were moistured with asepsis distilled water and kept suitable moisture, and the top of the Erlemeyer was sealed with asepsis plastic membrane. The samples were incubated at $35 \pm 1$ ${ }^{\circ} \mathrm{C}$. Samples were taken out at regular intervals and extracted for acetochlor analysis. Another set of samples was kept under asepsis condition as control experiments.

Adsorption distribution coefficients of acetochlor for soil samples were determined in duplicate using the batch equilibration method. For each determination, certain amount of soil samples were weighed into $50-\mathrm{mL}$ glass centrifuge tubes and $10 \mathrm{ml}$ of aqueous acetochlor solution of known concentrations ( $20,40,60,80$, and $100 \mathrm{mg} \mathrm{l}^{-1}$ ) was added to each tube. The acetochlor aqueous solutions contained $1 \% \mathrm{NaN}_{3}$ as a biocide. Tubes were sealed with Teflon-lined screw caps and mechanically shaken for $21 \mathrm{hr}$ at $25{ }^{\circ} \mathrm{C}$. After shaking, tubes were centrifuged for $15 \mathrm{~min}$ at $2500 \mathrm{rpm}$. $5-\mathrm{mL}$ aliquot of the supernatant was removed, filtered through $0.45 \mu \mathrm{m}$ filter membrane and placed in a glass tube for HPLC analysis of acetochlor

\section{RESULTS AND DISCUSSION}

The hydrolysis kinetic process of acetochlor can be described by the first-order reaction law and its rates in distilled and river waters were almost the same. $\mathrm{H}^{+}$can accelerate acetochlor hydrolysis. The hydrolysis rate constant in $\mathrm{pH} 4$ water was greater than in $\mathrm{pH} 7$ and $\mathrm{pH} 10$ waters. The hydrolysis half-live of acetochlor in $\mathrm{pH} 4, \mathrm{pH} 7$ and $\mathrm{pH} 10$ river waters were $1386 \mathrm{~d}$, $2310 \mathrm{~d}$ and $2310 \mathrm{~d}$, respectively.

The biodegradation behavior of a pesticide in soil is important in understanding its fate. The biodegradation processes of acetochlor in soils without and with HA and SDBS were measured during 35 days laboratory incubation. The biodegradation half-life in soils was 4.6 d. Addition of HA and SDBS decreased acetochlor biodegradation. The half-life was increased $17 \%$ and $33 \%$ by addition of HA and SDBS, respectively (Fig.1).

Acetochlor may form acetochlor-HA complex with HA. The complex has a much greater molecular and is easier to be adsorbed onto soil particles, and thus more difficult to be degraded by microorganism than under condition without HA. The biodegradation products of acetochlor in soil are very complex, but two compounds can be identified by GC/MASS, i.e. hydroxyacetochlor [2-hydroxy- N-(ethoxymethyl)-6'-ethylacet-o-toluidide] and 


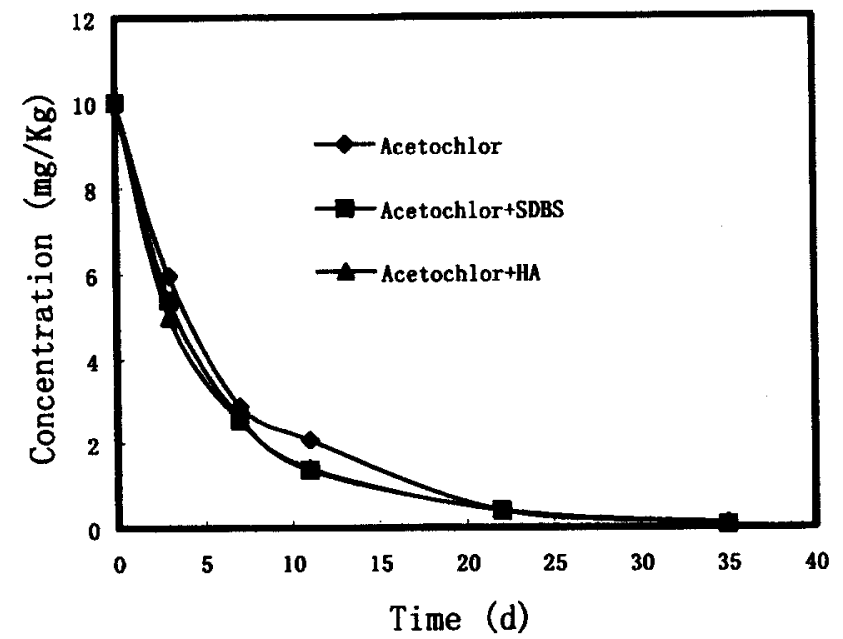

Figure 1. Biodegradation process of acetochlor in soil (Rate constants of biodegradation: Acetochlor only: $0.15 \mathrm{~d}^{-1}$; Acetochlor + SDBS: $0.11 \mathrm{~d}^{-1}$; Acetochlor + HA: $0.13 d^{-1}$ )

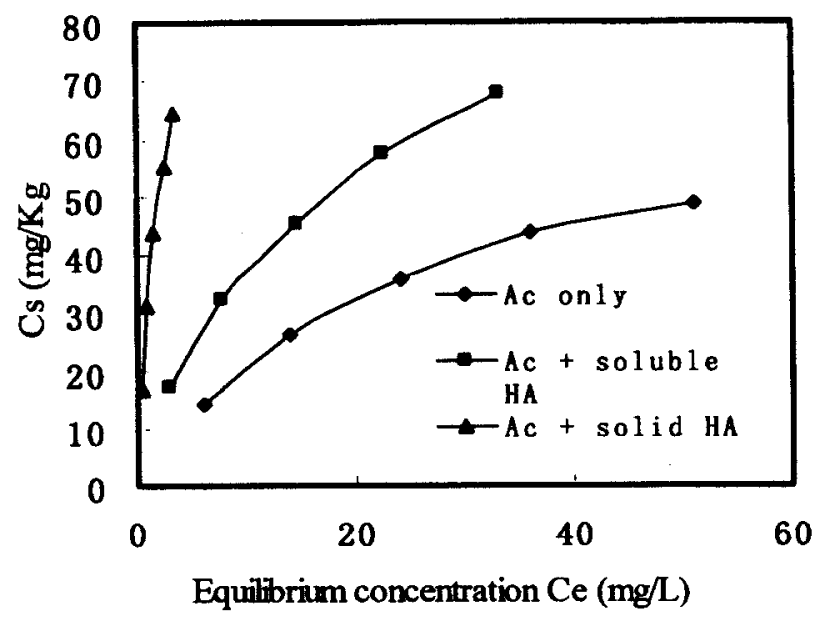

Figure 2. Adsorption isotherm of acetochlor to soil under soluble and solid HA (Ac: acetochlor)

2-methyl-6-ethylaniline.

In figure 2 and 3, Cs is the concentration of acetochlor adsorbed on soil ( $\mathrm{mg} \cdot \mathrm{kg}^{-1}$ ); Ce is the equilibrium concentration of acetochlor in solution (mg. $l^{-1}$ ). The calculated results were shown in table 2. The mean value of adsorption coefficient $K_{f}$ was $4.339 \mathrm{~L}^{\mathrm{kg}} \mathrm{kg}^{-1}$. Both solid and soluble HA increased adsorption capacity of acetochlor, but the former was greater than 


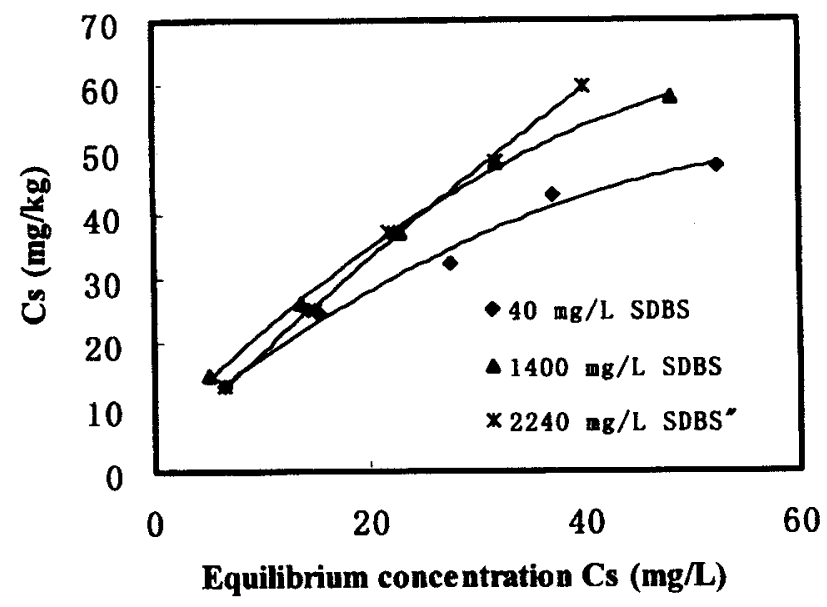

Figure 3. Adsorption isotherm of acetochlor to soil under SDBS

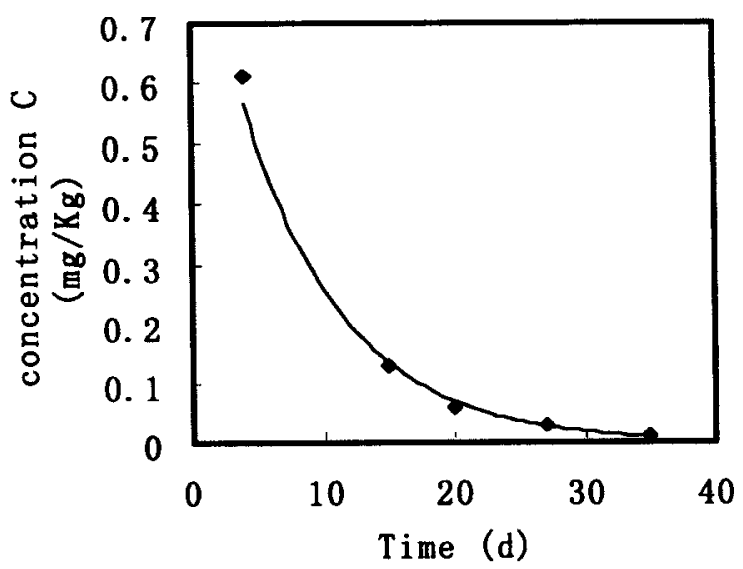

Figure 4. Dissipation process of acetochlor in surface $10 \mathrm{~cm}$ layer soil in corn field $C=0.9603 \mathrm{e}^{-0.1313 \mathrm{t}}$, $\mathbf{R}^{2}=0.9964$ )

the latter. Solid HA had great influence on acetochlor adsorption because solid HA in soil may be a sorbent itself, which played an important part in the adsorption of acetochlor.

The acetochlor could be solubilized at low SDBS concentration. The adsorption of acetochlor to soil could be increased at higher SDBS concentration since the soil surface might be completely covered by a monolayer of surfactant and the additional surfactant monomer might be adsorbed on the monolayer of hydrophobic heads. This would result in a bilayer of surfactant on the soil surface with surfactant hydrophobic tails sticking out in the aqueous phase, which would considerably enhance acetochlor adsorption to soil.

Dissipation of acetochlor in field soils is a result of combined action of biodegradation, photolysis, volatilization, leaching, runoff, and plant uptake. But the main processes are microbial degradation and leaching. Photolysis is not a main process because it can only 
occur in top $0.4 \mathrm{~mm}$ soils. The measured data of acetochlor concentration in soil samples, which were taken from the top $10 \mathrm{~cm}$ layer at corn field, were fitted to the first-order equation. The dissipation rate constant of acetochlor in surface layer soil was $0.13 \mathrm{~d}^{-1}$ ( Fig.4). Data in Fig. 4 were average values of two year measurements

Table 2. Freundlich constants describing adsorption of acetochlor to soils with some substances.

\begin{tabular}{lcll}
\hline Substances & $K_{f}$ & $1 / n$ & $R^{2}$ \\
Ac only & 4.339 & 0.636 & 0.992 \\
\hline Ac + soluble HA & 4.405 & 0.651 & 0.999 \\
Ac + solid HA & 9.572 & 0.572 & 0.996 \\
Ac $+40 \mathrm{mg} / \mathrm{L}$ SDBS & 4.303 & 0.62 & 0.989 \\
Ac $+1400 \mathrm{mg} / \mathrm{L}$ SDBS & 5.353 & 0.621 & 0.996 \\
Ac $+2240 \mathrm{mg} / \mathrm{L}$ SDBS & 5.489 & 0.789 & 0.995 \\
\hline
\end{tabular}

Ac: Acetochlor

By comparing the dissipation rate (rate constant $=0.13 \mathrm{~d}^{-1}$ ) and biodegradation rate (rate constant $=0.15 \mathrm{~d}^{-1}$ ), we found that the biodegradation rate under experimental conditions was greater than that under field conditions. Data from laboratory biodegradation measurement need to be calibrated before being used in field model calculation.

Environmental behavior of acetochlor in soils depends on intrinsic chemical properties and extrinsic environmental factors, such as soil properties and climatic conditions. Intrinsic acetochlor properties, such as vapor pressure, water solubility, biological activity and resistance to chemical changes, indicate the tendencies of herbicide fate, while extrinsic factors, such as soil microbial activity, soil organic carbon content, soil temperature, solar radiation and rainfall, and co-occurred other substances (e.g. HA and surfactants) can greatly modify the fate of acetochlor.

Acknowledgment. This work was supported by the National Natural Science Foundation of China (No. 29837170)

\section{REFERENCES}

Capel PD, Ma L, Schroyer BR, Larsen SJ, Gilchrist TA (1995) Analysis and detection of the new com herbicide acetochlor in river water and rain. Environ Sci Technol 29:1702-1705.

Clark GM, Goolsby DA (1999) Occurrence and transport of acetochlor in streams of the Missisipi River basin. J Environ Qual 28:1787-1795

Hendershot WH, Duquette M (1996) A simple brium chloride method for determining cation exchange capacity and changeable cation. Soil Soc America J 50:159-167.

Karlkhoff SJ, Kolpin DW, Thurman EM, Ferrer I, Barcelo (1998) Degradation of chloroacetanilide herbicide: The prevalence of sulfonic and oxanilic acid metabolites in lowa ground waters and surface waters. Environ Sci Technol 32:1738-1740.

USEPA (1994) Prevention, pesticides and toxic substances, questions and answers, conditional registration of acetochlor, USEPA, Washington, DC, Mar 11, 1994, 18pp.

Wang, L. (1999) A survey and development trend of Chinese pesticide industry. Pesticides 38:1-8. 